\title{
Czynniki wyboru i satysfakcji z usług świadczonych przez lokale fast food w świetle badań klientów i pracowników
}

\section{Wstęp}

Gastronomia w Polsce należy do najszybciej rozwijających się działów gospodarki narodowej i charakteryzuje się dużą dynamiką rozwoju. Na skalę i strukturę działalności gastronomicznej bezpośrednio wpływają konsumenci, którzy mają coraz większą siłę nabywczą oraz zasoby czasu wolnego. Jednocześnie na kształtowanie samej usługi gastronomicznej i jej odbiór ma wpływ personel, zwłaszcza pierwszego kontaktu. Zjawisko to dotyczy współcześnie również lokali typu fast food, które aspirują do bycia miejscem spotkań dla klientów, a nie tylko spożywania szybkich posiłków przy zminimalizowanej obsłudze. Należy również dodać, że personel często bardziej obiektywnie ocenia motywy wyboru i satysfakcji klientów na podstawie ich obserwacji; ocena klienta jest bowiem zawsze obarczona błędem subiektywizmu.

\section{Determinanty rozwoju współczesnego rynku usług gastronomicznych}

Uwarunkowania popytowe rozwoju rynku usług gastronomicznych wiążą się z poziomem rozwoju gospodarczego w ujęciu makro- (produkt krajowy, stopa bezrobocia itd.) i mikroekonomicznym (sytuacja dochodowa, struktura wydatków, w tym na żywność, przemiany społeczno-demograficzno-kulturowe itd). Coraz mniejsze obawy o utratę pracy, a także wzrost wynagrodzeń, emerytur i rent sprawiły, iż społeczeństwo polskie jest bardziej skłonne do wydawania pieniędzy, w tym na usługi gastronomiczne [Kwiatkowska, Levytska 2009]. 
Wśród innych uwarunkowań wpływających na rozwój usług gastronomicznych na początku XXI wieku należy również wymienić: zmianę struktury demograficznej ludności: wzrost udziału 1- i 2-osobowych gospodarstw domowych; przedłużenie się życia oraz wzrost liczby ludzi w wieku poprodukcyjnym; wzrost poziomu wykształcenia i kwalifikacji ludności; zwiększenie zawodowej aktywności kobiet; zmiany w sposobie gospodarowania czasem; rozwój rynków usługowych związanych z czasem wolnym; wzrost zainteresowania kulturą innych narodów; zmiany postaw i motywacji konsumentów; rozwój ruchu turystycznego [Knowles 2001, Sala 2004].

Czynnikami pobudzającymi popyt na usługi gastronomiczne i zwiększającymi ich znaczenie społeczne są industrializacja i urbanizacja wraz ze wszystkimi towarzyszącymi im zmianami społecznymi, takimi jak: zmiana struktury rodziny, zwiększenie liczby osób pracujących poza domem, zmiany w sposobie gospodarowania czasem, duże obciążenie pracą i nauką poza domem, oddalenie od miejsca zamieszkania [Masłowski 2000]. Coraz częściej zwraca się uwagę na wzrost części dochodów, którą konsumenci wydają na usługi związane z wypoczynkiem, rozrywkami, podróżami i gastronomią [Payne, Holt 2001].

Jedną z cech charakterystycznych współczesnej gastronomii jest dynamika zachodzących w niej zjawisk. W Polsce w ciagu ostatnich 20 lat zaszły znaczne przeobrażenia rynku gastronomicznego. Miały na to wpływ tzw. megatrendy, czyli powszechne zjawiska o globalnym zasięgu i procesy gospodarczo-społeczne, polityczne czy kulturowe, mające silny wpływ na charakter i kierunki procesów gospodarczych w większości państw, implikujące określone prawidłowości i mechanizmy rozwoju branży [Milewska i in. 2010]. Wzrost dochodów ludności, aktywizacja zawodowa kobiet oraz większa ilość czasu wolnego powodują, że Polacy coraz chętniej jedzą poza domem, a wzrost znaczenia turystyki międzynarodowej sprawia, że do kraju przyjeżdża coraz więcej cudzoziemców. Powstają sieci barów i restauracji, rozwija się baza noclegowa, a wraz z nią oferta gastronomiczna. Rozwój usług gastronomicznych wywiera znaczący wpływ na prowadzenie gospodarstwa domowego, styl odżywiania, przemiany w strukturze czynności wypełniających czas wolny. Usługi gastronomiczne wpływają pozytywnie na poziom i jakość życia [Kwiatkowska 2009, Levytska 2011].

W ostatnich latach można zaobserwować, iż lokale sieci gastronomicznych typu fast food starają się rozszerzyć okoliczności korzystania z ich usług, realizują przez to szersze potrzeby niż tylko zaspokajania głodu. Sieć McDonald's nie tylko zmieniła wystrój, ale również rozszerza asortyment i stara się realizować funkcje społeczne w swoich lokalach m.in. w przekazach promocyjnych przedstawia je jako miejsce spotkań. W związku z powyższym w artykule podjęto się przeanalizowania czynników wyboru i satysfakcji w lokalach typu fast food. 


\section{Czynniki wyboru i satysfakcji klienta w lokalach gastronomicznych}

Korzystanie z usług gastronomicznych stanowi - zwłaszcza w dużych miastach - element stylu życia, co powoduje wzrost znaczenia lojalności konsumenckiej. Pojęcie „lojalność klienta” jest rozumiane na wiele sposobów. Do pewnego czasu przyjmowano, że wiąże się ono z wielokrotnymi zakupami u tego samego dostawcy, ale odpowiedniejsze jest przyjęcie definicji, iż lojalny konsument często dokonuje zakupów u jednego dostawcy i jednocześnie ma o nim pozytywną opinię [Skogland, Siguaw 2004]. Lojalnego klienta restauracji scharakteryzować można w sposób następujący:

- dokonuje regularnych, a co za tym idzie - powtarzalnych zakupów w wybranym lokalu gastronomicznym,

- nabywa różnorodne produkty oferowane przez lokal,

- upowszechnia pozytywne informacje o ofercie lokalu,

- upowszechnia pozytywne informacje o jakości usług realizowanych przez lokal, w tym również o obsłudze,

- jest odporny na działania oraz promocje podejmowane przez konkurentów,

- jasno wyraża intencję powtórnej wizyty.

Można stwierdzić, że lojalność polega nie tylko na dokonywaniu zakupu; prawdziwą lojalność mogą wykazywać tylko klienci bardzo przywiązani do dostawcy, a zadowolenie klienta to wskaźnik lojalności. Podstawą zrozumienia lojalności jest analiza czynników satysfakcji klientów, ponieważ satysfakcja $\mathrm{z}$ usługi gastronomicznej jest elementem niezbędnym do wytworzenia lojalnej postawy gości lokali gastronomicznych. Satysfakcja klienta wynika zazwyczaj z ogólnej oceny jakości usługi. Sprostanie lub przewyższenie oczekiwań klienta w zakresie jakości usługi składającej się w przypadku gastronomii z żywności, obsługi i wystroju lokalu gastronomicznego, stanowi podstawę wystąpienia satysfakcji, a w dłuższej perspektywie może sprawić, iż klienci będą wracać do lokalu gastronomicznego [Liu i in. 2015, Stangierska i Świątkowska 2012].

W przypadku usług gastronomicznych na ogólną ocenę jakości składają się takie czynniki, jak: jakość żywności, otoczenie świadczenia usługi (wystrój i atmosfera lokalu gastronomicznego) oraz obsługa. Na jakość żywności składa się wiele czynników związanych nie tylko z oceną sensoryczną potraw czy ich świeżością, ale także z wartością odżywczą, sposobem podania potrawy, relacją ceny do jakości oraz wielkością porcji [Markovic i in. 2011].

Kolejnym elementem wpływającym na jakość usługi gastronomicznej jest otoczenie fizyczne, obejmujące takie elementy materialne jak wyposażenie, elementy dekoracyjne, jak również elementy niematerialne, takie jak muzyka, za- 
pach temperatura w lokalu itp. Wygląd i wystrój lokalu są silną determinantą powstawania lojalności i satysfakcji w szczególności w przypadku restauracji [Stangierska 2013].

Specyfika usług gastronomicznych sprawia, iż ważną grupę czynników wpływających na ich jakość, a co za tym idzie satysfakcję klienta, stanowią elementy związane z obsługą. Do determinantów jakości obsługi należą cechy związane z personelem, takie jak: wiedza, profesjonalizm, empatia, sposób komunikacji, ale także elementy związane $\mathrm{z}$ formami płatności, szybkością i zakresem serwisu [Ramanathan i in. 2016].

Wiedza pracowników lokalu gastronomicznego nie powinna ograniczać się tylko do zakresu ich obowiązków związanych z świadczeniem usługi klientom. Personel pierwszego kontaktu jest świadom zarówno swojej roli w procesie świadczenia usługi gastronomicznej, jak i znaczenia jej innych składowych. Do wzrostu świadomości personelu w zakresie czynników satysfakcji klienta przyczyniają się nie tylko oceny pracownicze, ale coraz popularniejsze przeprowadzanie badań typu tajemniczy klient [Liu i in. 2015]. Dodatkowo zadowolenie klienta $\mathrm{z}$ obsługi znajduje odzwierciedlenie $\mathrm{w}$ wysokości napiwków, ale także powoduje wzrost podatności na działania zwiększające sprzedaż, takie jak wzrost wielkości i wartości zamówienia [Lin, Namasivayam 2011].

Świadomość klientów i pracowników gastronomii w zakresie zarówno determinantów jakości usługi gastronomicznej, jak i satysfakcji jest odmienna. Klienci bazują na oczekiwaniach oraz wcześniejszych doświadczeniach. Personel pierwszego kontaktu posiada wiedzę wynikająca $\mathrm{z}$ wykonywania zawodu. W niniejszym artykule za cel postawiono porównanie perspektywy klientów i personelu w zakresie czynników jakości i satysfakcji z usług świadczonych w lokalach typu fast food.

\section{Materiał i metodyka}

Celem badania było porównanie czynników kształtujących wybór i satysfakcję konsumentów i pracowników sieci restauracji McDonald's w zakresie świadczonych usług i jakości produktów. Niniejsze opracowanie ma na celu wyjaśnienie, jakie czynniki w największym stopniu wpływają na wybór i satysfakcję klientów i pracowników tego typu lokali.

Narzędziem badawczym były dwie anonimowe ankiety skierowane do konsumentów i pracowników tego typu lokali gastronomicznych, którzy oceniali jakość usług świadczonych $\mathrm{w}$ lokalach gastronomicznych restauracji McDonald's. 
Badanie konsumentów zostało przeprowadzone w Warszawie na próbie 98 osób dorosłych (w wieku powyżej 18 lat), korzystających jedno- lub wielokrotnie z usług lokali McDonald's. Drugą grupę badanych stanowiło 50 pracowników tych restauracji. Badania zostały przeprowadzone we wrześniu 2015 roku w 7 wybranych restauracjach McDonald's na terenie Warszawy. Restauracje wybrane w celu przeprowadzenia badań charakteryzowały się takimi wspólnymi cechami, jak: duże znaczenie lokalizacji (np. blisko Starego Miasta, centrum Warszawy), duże natężenie ruchu klientów, różnorodność konsumentów (np. duża liczba obcokrajowców, turystów). W każdej placówce zostało zbadanych 10-14 klientów i 6-8 pracowników.

\section{Wyniki badań}

Największe różnice $\mathrm{w}$ opiniach konsumentów i pracowników dotyczyły takich czynników wpływających na wybór lokalu, jak: smak oferowanych produktów i czas realizacji zamówień (odpowiednio - 0,65 i -0,64); czynniki te uzyskały znacznie większą średnią rang od klientów. Duża różnica w średniej rang dotyczyła czynnika poziomu obsługi klienta (został on wyżej oceniony przez pracowników), co może świadczyć o wysokiej samoocenie obsługi przez pracowników. Nieco mniejsze różnice opinii pracowników i klientów dotyczyły bezpieczeństwa oferowanych produktów $(0,34)$. Podobne różnice w rangowaniu przez pracowników i konsumentów miały miejsce w przypadku takich czynników, jak czystość w restauracji i jakość oferowanych produktów (odpowiednio $0,28$ i 0,29$)$ oraz lokalizacja lokalu i jego wystrój (po 0,06) - te czynniki zostały wyżej ocenione przez pracowników. Najmniejsza różnica ocen wystąpiła w przypadku poziomu cen $(-0,15)$, a także znanej marki $(-0,2)$, które zostały ocenione nieco wyżej przez klientów (tab. 1).

W pytaniu o ocenę stwierdzeń klientów i pracowników dotyczących jakości usług w McDonald's wynika, że największe rozbieżności dotyczyły dostępności informacji o wartości odżywczej $(-0,46)$, tego, że McDonald's można nazwać „miejscem spotkań” $(-0,39)$ oraz przystosowania lokali do potrzeb osób niepełnosprawnych $(-0,36)$. Nieznacznie różnią się oceny jakości świadczonych usług i rodzinnej atmosfery panującej w placówkach McDonald's (odpowiednio - 0,26 i-0,3), co może wynikać z różnicy punktów widzenia na ten temat pracowników i klientów firmy. Najmniejszą rozbieżność wyników stwierdzono w przypadku satysfakcjonującego poziomu obsługi w lokalach i uprzejmej obsługi klientów (po -0,1), zróżnicowanego wyboru oferowanych dań $(-0,15)$; wszystkie wymienione czynniki zostały wyżej ocenione przez pracowników. Różnice w zakresie adekwatności poziomu cen do jakości dań i usług $(0,03)$ oraz czasu realizacji 
Tabela 1

Porównanie rangi czynników wyboru restauracji McDonald's przez klientów i pracowników

\begin{tabular}{|l|c|c|c|}
\hline \multicolumn{1}{|c|}{ Wyszczególnienie } & $\begin{array}{c}\text { Średnia rang } \\
\text { klientów* }^{*}\end{array}$ & $\begin{array}{c}\text { Średnia rang } \\
\text { pracowników* }\end{array}$ & $\begin{array}{c}\text { Różnica } \\
\text { ( ś.r. klientów - ś.r. } \\
\text { pracowników) }\end{array}$ \\
\hline $\begin{array}{l}\text { Smak oferowanych } \\
\text { produktów }\end{array}$ & 3,87 & 4,52 & $-0,65$ \\
\hline Czas realizacji zamówienia & 4,92 & 5,56 & $-0,64$ \\
\hline Lokalizacja lokalu & 4,98 & 4,92 & 0,06 \\
\hline Poziom cen & 5,01 & 5,16 & $-0,15$ \\
\hline $\begin{array}{l}\text { Jakość oferowanych } \\
\text { produktów }\end{array}$ & 5,31 & 5,02 & 0,29 \\
\hline $\begin{array}{l}\text { Bezpieczeństwo } \\
\text { oferowanych produktów }\end{array}$ & 5,7 & 5,36 & 0,34 \\
\hline Czystość w restauracji & 5,82 & 5,54 & 0,28 \\
\hline Poziom obsługi klienta & 5,97 & 5,32 & 0,65 \\
\hline Znana marka & 6,58 & 6,78 & $-0,2$ \\
\hline Wystrój lokalu & 6,88 & 6,82 & 0,06 \\
\hline
\end{tabular}

*Szeregowanie/rangowanie odpowiedzi na 10-stopniowej skali rangowej, gdzie 1 - czynnik najważniejszy, 10 - najmniej ważny.

Źródło: Badanie własne 2015.

zamówień $(0,08)$ są niewielkie; czynniki te zostały nieznacznie wyżej ocenione przez konsumentów. Takie wyniki świadczą o dużym podobieństwie opinii konsumentów i pracowników na temat usług świadczonych przez firmę McDonald's pod względem różnych czynników wpływających na satysfakcję klientów (tab. 2).

Największa różnica w odpowiedziach konsumentów i pracowników dotyczyła dostępności informacji o wartości odżywczej na produktach oferowanych w lokalach McDonald's. Taki wynik może świadczyć o większej świadomości pracowników w zakresie dostępności informacji żywieniowej w tychże lokalach. Również w przypadku stwierdzenia: „McDonald's można nazwać miejscem spotkań" i dotyczącego uprzejmości obsługi w lokalach można zauważyć, że zostały one wyżej ocenione przez pracowników niż przez klientów, co może świadczyć o lepszej znajomości przez pracowników komunikatów marketingowych stosowanych w przekazach medialnych.

W pytaniu o ocenę oferty lokali McDonald's największa różnica opinii pracowników i klientów dotyczyła czynnika „cena” $(0,76)$, który został znacznie wyżej oceniony prze klientów niż pracowników. Może to być spowodowane brakiem specjalnych ofert dla pracowników i dostępnością programów rabatowych skierowanych do konsumentów. Mniejsze rozbieżności opinii dotoczyły 
Tabela 2

Porównanie oceny stwierdzeń klientów i pracowników dotyczących jakości usług lokali McDonald's

\begin{tabular}{|c|c|c|c|}
\hline Wyszczególnienie & $\begin{array}{c}\text { Ocena } \\
\text { klientów* }\end{array}$ & $\begin{array}{c}\text { Ocena } \\
\text { pracowników* }\end{array}$ & $\begin{array}{l}\text { Różnica (ocena klientów } \\
\text { - ocena pracowników) }\end{array}$ \\
\hline $\begin{array}{l}\text { Poziom obsługi w lokalach } \\
\text { McDonald's uważam za satys- } \\
\text { fakcjonujący }\end{array}$ & 3,74 & 3,84 & $-0,1$ \\
\hline $\begin{array}{l}\text { Wybór dań oferowanych przez } \\
\text { restauracje McDonald's jest bar- } \\
\text { dzo zróżnicowany }\end{array}$ & 3,53 & 3,68 & $-0,15$ \\
\hline $\begin{array}{l}\text { Jakość usług gastronomicznych } \\
\text { świadczonych przez zakłady } \\
\text { McDonald's jest bardzo dobra }\end{array}$ & 3,42 & 3,68 & $-0,26$ \\
\hline $\begin{array}{l}\text { Poziom cen w lokalach } \\
\text { McDonald's jest adekwatny } \\
\text { do jakości }\end{array}$ & 3,47 & 3,44 & 0,03 \\
\hline $\begin{array}{l}\text { Restauracje McDonald's są bar- } \\
\text { dzo dobrze przystosowane dla } \\
\text { potrzeb osób niepełnosprawnych }\end{array}$ & 3,54 & 3,9 & $-0,36$ \\
\hline $\begin{array}{l}\text { Informacja o wartości odżywczej } \\
\text { (wartość energetyczna, ilość } \\
\text { białka. tłuszczów itd.) produktów } \\
\text { oferowanych przez McDonald’s } \\
\text { jest łatwo dostępna w restaura- } \\
\text { cjach }\end{array}$ & 4,06 & 4,52 & $-0,46$ \\
\hline $\begin{array}{l}\text { McDonald's można nazwać } \\
\text { „miejscem spotkań” }\end{array}$ & 3,71 & 4,1 & $-0,39$ \\
\hline $\begin{array}{l}\text { Restauracje McDonald's są miej- } \\
\text { scem, gdzie można zjeść posiłek } \\
\text { razem z rodziną }\end{array}$ & 3,46 & 3,76 & $-0,3$ \\
\hline $\begin{array}{l}\text { Czas realizacji zamówień } \\
\text { w restauracjach McDonald's jest } \\
\text { odpowiedni dla restauracji typu } \\
\text { fast food }\end{array}$ & 3,98 & 3,9 & 0,08 \\
\hline $\begin{array}{l}\text { Obsługa w lokalach McDonald's } \\
\text { jest uprzejma dla klientów }\end{array}$ & 3,90 & 4,0 & $-0,1$ \\
\hline
\end{tabular}

*Oceny na skali 5-stopniowej, gdzie 1 - zdecydowanie się nie zgadzam, 5 - zdecydowanie się zgadzam.

Źródło: Badanie własne 2015. 
takich czynników, jak jakość potraw $(-0,23)$, nowe produkty w menu $(-0,22)$, obsługa $(-0,16)$, wygląd $(-0,05)$ i atmosfera lokalu $(-0,06)$ - czynniki te zostały wyżej ocenione przez pracowników. Najmniejsze różnice oceny stwierdzono w przypadku takich czynników, jak promocje i konkursy $(0,2)$, menu $(0,08)$, smak potraw $(0,12)$ i czystość lokalu $(0,13)$ - czynniki te zostały wyżej ocenione przez klientów (tab. 3).

Tabela 3

Porównanie oceny oferty lokali McDonald's przez pracowników i klientów

\begin{tabular}{|l|c|c|c|}
\hline \multicolumn{1}{|c|}{ Wyszczególnienie } & $\begin{array}{c}\text { Ocena } \\
\text { klientów* }\end{array}$ & $\begin{array}{c}\text { Ocena } \\
\text { pracowników* }\end{array}$ & $\begin{array}{c}\text { Różnica (ocena klientów } \\
\text { - ocena pracowników) }\end{array}$ \\
\hline Wygląd lokalu & 4,23 & 4,18 & 0,05 \\
\hline Czystość lokalu & 4,17 & 4,04 & 0,13 \\
\hline Promocje/konkursy & 4,12 & 3,92 & 0,2 \\
\hline Obsługa & 4,04 & 4,2 & $-0,16$ \\
\hline Atmosfera & 4,02 & 4,08 & $-0,06$ \\
\hline Smak potraw & 3,98 & 3,86 & 0,12 \\
\hline Menu & 3,94 & 3,86 & 0,08 \\
\hline Nowe produkty w menu & 3,94 & 4,16 & $-0,22$ \\
\hline Cena & 3,86 & 3,1 & 0,76 \\
\hline Jakość potraw & 3,71 & 3,94 & $-0,23$ \\
\hline
\end{tabular}

*Ocena na skali 5-stopniowej, gdzie 1 - ocena najniższa, 5 - najwyższa.

Źródło: Badanie własne 2015.

W pytaniu o najważniejsze aspekty jakości w zakładach gastronomicznych McDonald's, zarówno klienci, jak i pracownicy najczęściej wskazywali na cenę produktów i ich smak. Największa rozbieżność wskazań klientów i pracowników dotyczyła profesjonalizmu obsługi, który w przypadku pracowników był trzecim najważniejszym czynnikiem jakości, z kolei w przypadku klientów uzyskał o 3,8\% wskazań mniej i zajmował dopiero piątą pozycję po czystości wnętrza i wygodzie. Pracownicy cześciej wskazywali także na znaczenie takich aspektów, jak wystrój i kolorystyka wnętrza (2,7\% więcej wskazań), powtarzalność usługi ( $1,9 \%$ więcej wskazań) oraz atmosfera/klimat (1,2\% więcej wskazań). Dla klientów ważniejsze niż dla pracowników były takie aspekty, jak wygoda (o 2,5\% więcej wskazań), gadżety do zestawów (tylko klienci podali ten element jako czynnik jakości) oraz cena, atrakcyjny wygląd produktu spożywczego i wartość odżywcza (o 1,8\% wskazań więcej) - tabela 4. 
Tabela 4

Porównanie wskazań respondentów dotyczących najważniejszych aspektów jakości w lokalach McDonald's

\begin{tabular}{|l|c|c|c|}
\hline \multicolumn{1}{|c|}{ Wyszczególnienie } & $\begin{array}{c}\% \text { wskazań } \\
\text { klientów* }\end{array}$ & $\begin{array}{c}\% \text { wskazań } \\
\text { pracowników* }\end{array}$ & $\begin{array}{c}\text { Różnica (\% wskazań } \\
\text { klientów - \% wskazań } \\
\text { pracowników) }\end{array}$ \\
\hline Cena & 19,8 & 18,0 & 1,8 \\
\hline Smak & 15,0 & 16,0 & $-1,0$ \\
\hline Czystość wnętrza & 9,6 & 8,0 & 1,6 \\
\hline Wygoda & 9,2 & 6,7 & 2,5 \\
\hline Profesjonalna obsługa & 8,9 & 12,7 & $-3,8$ \\
\hline Czystość toalet & 6,8 & 6,7 & 0,2 \\
\hline $\begin{array}{l}\text { Atrakcyjny wygląd } \\
\text { produktu spożywczego }\end{array}$ & 6,5 & 4,7 & 1,8 \\
\hline Atmosfera/klimat & 5,5 & 6,7 & $-1,2$ \\
\hline Wartość odżywcza & 5,1 & 3,3 & $-1,9$ \\
\hline Powtarzalność & 4,8 & 6,7 & $-0,6$ \\
\hline Urozmaicenie składników & 4,8 & 5,3 & 2,4 \\
\hline $\begin{array}{l}\text { Gadżety do zestawów } \\
\text { (np. zabawki, balony) }\end{array}$ & 2,4 & 0,0 & $-1,0$ \\
\hline $\begin{array}{l}\text { Przystosowanie dla } \\
\text { potrzeb osób niepełno- } \\
\text { sprawnych }\end{array}$ & 1,0 & 2,0 & $-2,7$ \\
\hline $\begin{array}{l}\text { Wystrój/kolorystyka } \\
\text { wnętrza }\end{array}$ & 0,7 & 3,3 & \\
\hline
\end{tabular}

* Można było wskazać maksymalnie 3 czynniki.

Źródło: Badanie własne 2015.

\section{Wnioski}

Wyniki badań wskazuja, że dla badanych klientów najważniejszymi czynnikami kształtującymi satysfakcję i wpływającymi na wybór lokalu są smak oferowanych produktów, czas realizacji zamówienia i lokalizacja, o czym świadczą wysokie oceny tych czynników w opinii konsumentów. Duże znaczenie przy ocenie atrakcyjności oferty firmy McDonald's mają również takie aspekty, jak poziom cen i jakość oferowanych produktów, w przeciwieństwie do wystroju i znanej marki, które tylko nieznacznie wpływają na opinię klientów. Świadczy to o tym, że konsumenci korzystający z usług McDonald's zwracają szczególną 
uwagę na rdzeń usługi gastronomicznej, czyli elementy związane bezpośrednio z samym produktem bądź procesem świadczenia usługi, determinantami ich wyboru jest zaś w niewielkim stopniu rozpoznawalna marka. Uzyskane wyniki pokazują, iż konsumenci w badaniach deklaratywnych dotyczących wyboru wykazują racjonalne podejście.

W przypadku pracowników zakres czynników kształtujących satysfakcję korzystania z usług McDonald's był znacznie szerszy niż w przypadku klientów. Warto podkreślić, iż w przypadku pierwszych dwóch czynników (smaku i czasu realizacji zamówienia) opinie pracowników i klientów były zbieżne z opiniami klientów. Jednak pracownicy przywiązywali większą wagę do takich czynników, jak: jakość i bezpieczeństwo oferowanych produktów, poziom obsługi klienta. Może to wynikać z większej świadomości pracowników w zakresie złożoności wyboru usługi gastronomicznej. Pracownicy także cenią wyżej obsługę niż klienci, co może świadczyć o większej świadomości nakładu pracy związanego z świadczeniem usług gastronomicznych.

W zakresie oceny jakości usług świadczonych przez lokale sieci McDonald's zarówno klienci, jak i pracownicy za najważniejsze uznali dostępność informacji o wartości odżywczej w lokalach sieci i uprzejmość obsługi, natomiast w opinii pracowników fakt, że McDonald's można nazwać miejscem spotkań. Największe różnice w opiniach pracowników i klientów stwierdzono w przypadku dostępności informacji o wartości odżywczej dań serwowanych w lokalach sieci oraz tego, że lokale te można uznać za miejsce spotkań; w obu przypadkach czynniki te zostały znacznie wyżej ocenione przez pracowników. Może to świadczyć o zbyt optymistycznym podejściu pracowników co do dostępności informacji żywieniowej w lokalach oraz obserwacji zachowań klientów w zakresie sposobu korzystania z lokalu. Dla pracowników miejsce spotkań może być rozumiane bezpośrednio (ludzie często spotykają się w łatwo dostępnych lokalach sieci), klienci natomiast mogą oceniać je niżej w porównaniu do innych placówek gastronomicznych.

Klienci najwyżej ocenili wygląd, czystość lokalu i promocje/konkursy organizowane przez firmę McDonald's, natomiast w ocenie pracowników największe znaczenie mają obsługa, wygląd lokalu, a także nowe produkty w menu. Istotne różnice w ocenie klientów i pracowników dotyczyły znaczenia ceny, do której znacznie większe znaczenie przywiązują klienci. Można zatem stwierdzić, że dla klientów większe znaczenie w ocenie lokali sieci McDonald's mają elementy otoczenia materialnego i akcje promocyjne, jak również ceny. W subiektywnej ocenie pracowników większe znaczenie ma obsługa.

Wśród trzech najważniejszych przy ocenie lokali McDonald's czynników zarówno klienci, jak i pracownicy najczęściej wskazywali na cenę i smak. Klienci na trzecim miejscu wskazywali na czystość wnętrza, a z kolei pracownicy na 
profesjonalną obsługę. Największe różnice wskazań dotyczyły profesjonalizmu obsługi, co świadczy z jednej strony o dużym znaczeniu tych czynników dla wyboru lokali sieci McDonald's, jak również o dużych rozbieżnościach w ich ocenie przez pracowników i klientów.

Uzyskane wyniki pokazują że klienci i pracownicy są zbieżni w swoich deklaracjach na temat zarówno czynników wyboru, jak i satysfakcji. Zauważone różnice w największym stopniu dotyczą oceny aspektów związanych z obsługą która jest wyżej oceniana przez pracowników. Klienci w swoich opiniach przejawiają racjonalizm, ich opinie są silniej spolaryzowane, a różnice między najważniejszymi i najmniej istotnymi czynnikami bardzo wyraźne. Pracownicy wykazują zaś tendencję do rozpatrywania szerzej zarówno czynników wyboru, jak i satysfakcji, co przejawia się w mniejszych różnicach ocen poszczególnych czynników.

\section{Literatura}

KNOWLES T., 2001: Zarzqdzanie hotelarstwem i gastronomiq, PWE, Warszawa

KWIATKOWSKA E., 2009: Wybrane uwarunkowania demograficzne korzystania z ustug gastronomicznych (na przykladzie aglomeracji warszawskiej), [w:] Zeszyty Naukowe Szkoły Głównej Gospodarstwa Wiejskiego. Ekonomika i Organizacja Gospodarki Żywnościowej 80, 61-68

KWIATKOWSKA E., LEVYTSKA G., 2009: Rynek ustug gastronomicznych w Polsce na poczatku XXI w., [w:] Zeszyty Naukowe Szkoły Głównej Gospodarstwa Wiejskiego. Ekonomika i Organizacja Gospodarki Żywnościowej 74, 91-102.

LEVYTSKA G., 2011: Usługi gastronomiczne - znaczenie i tendencje rozwoju, Wydawnictwo Szkoły Głównej Gospodarstwa Wiejskiego, Warszawa.

LIN I.Y., NAMASIVAYAM K., 2011: Understanding Restaurant Tipping Systems: A Human Resources Perspective, International Journal of Contemporary Hospitality Management 23 (7), 923-940.

LIU C., CHOU S., GAN B., TU J., 2015: How “Guality” Determines Customer Satisfaction Evidence from the Mystery Shoppers' Evaluation, TQM Journal 27 (5), 576-590

MARKOVIC S., RASPOR S., DORCIC J., 2011: What are the key dimensions of restaurant service quality? An empirical study in the city restaurant settings, Sustainable Tourism: Socio-Cultural, Environmental and Economics Impact 1, 235-249.

MASŁOWSKI A., 2000: Rynek ustug gastronomicznych. Uwarunkowania i kierunki rozwo$j u$, Wydawnictwo UMSC, Lublin.

MILEWSKA M., PRĄCZKO A., STASIAK A., 2010: Podstawy gastronomii, PWE, Warszawa.

PAYNE A., HOLT S., 2001: Diagnosing Customer Value: Integrating the Value Process and Relationship Marketing, [w:] British Journal of Management 12, London 3-27. 
RAMANATHAN R., DI Y. RAMANATHAN U., 2016: Moderating Roles of Customer Characteristics on the Link Between Service Factors and Satisfaction in a Buffet Restaurant, Benchmarking 23 (2), 469-486.

SALA J., 2011: Marketing $w$ gastronomii, PWE, Warszawa.

SKOGLAND I., SIGUAW J.A., 2004: Are Your Satisfied Customers Loyal? Cornell Hotel and Restaurant Administration Quarterly 45 (3), 221-234.

STANGIERSKA D., 2013: Otoczenie fizyczne ustugi i jego konsekwencje wizerunkowe - przykład marki sieci restauracji casual dining, Zeszyty Naukowe Szkoły Głównej Gospodarstwa Wiejskiego. Polityki Europejskie, Finanse i Marketing 10(59), 662-672.

STANGIERSKA D., ŚWIĄTKOWSKA M., 2012: Metody oceny satysfakcji konsumentów na rynku usług [w:] Z. Waśkowski, M. Sznajder (red.), Nowe trendy w dystrybucji produktów żywnościowych: gastronomia i zachowania nabywców, 164-173

StatSoft Polska, 2003: Analiza satysfakcji i lojalności klientów, Warszawa - Kraków, 19-25.

\section{Abstrakt}

Celem opracowania było porównanie czynników kształtujących wybór i satysfakcję konsumentów ze świadczonych usług i jakości produktów na przykładzie sieci restauracji fast food. Na podstawie badań zarówno klientów jak i pracowników, podjęto się próby wyjaśnienia, jakie czynniki w największym stopniu wpływają na wybór i satysfakcję w opinii klientów i pracowników tego typu lokali. Stwierdzono, iż zarówno w przypadku klientów jak i pracowników do najważniejszych czynników wyboru i satysfakcji z usługi gastronomicznej należą smak oferowanych produktów, czas realizacji zamówienia i lokalizacja; duże znaczenie dla klientów ma również korzystna relacja ceny do jakości oferowanych potraw. Zauważone różnice w największym stopniu dotyczą oceny aspektów związanych z obsługą, która jest wyżej oceniana przez pracowników. Klienci w swoich opiniach przejawiają racjonalizm, ich opinie są silniej spolaryzowane a różnice między najważniejszymi i najmniej istotnymi czynnikami bardzo wyraźne. Pracownicy wykazują zaś tendencję do rozpatrywania szerzej zarówno czynników wyboru jak i satysfakcji, co przejawia się w mniejszych różnicach ocen poszczególnych czynników.

Słowa kluczowe: czynniki wyboru, lojalność klienta, gastronomia, fast food 


\title{
Service quality and satisfaction factors of fast food services in the light of customer and employee surveys
}

\begin{abstract}
The aim of the study was to compare the consumers' choice and satisfaction factors with provided services and product quality on the example of a fast food restaurant chain. Based on the research of both clients and employees, attempts were made to clarify which factors affect the customers choice and satisfaction and staff in this type of gastronomy. It was found that both for customers and employees, the most important factors in the selection and satisfaction of the gastronomy services are the taste of the offered products, the time of order fulfillment and location. High importance for customers also has a favorable price relationship to the quality of the offered dishes. The differences observed are most closely related to the assessment of the service aspects, which are assessed above by the staff. Customers in their opinions show rationalism, their opinions are stronger polarized and the differences between the most important and least important factors are very clear. Employees tend to consider both the choice and satisfaction factors more broadly, which is reflected in the smaller differences in evaluations of individual factors.
\end{abstract}

Key words: choice factors, customer loyalty, gastronomy, fast food 